\title{
From Erotic to Esoteric: The Relation of Imagination- Creative of Sufistic Literature
}

\author{
Khairul Fuad ${ }^{1}$, Syarifah Lubna ${ }^{2}$, Binar Kurniasari Febrianti ${ }^{3}$, Dewi Juliastuty ${ }^{4}$ \\ \{khairulfuad297@gmail.com¹, lubna.alkadrie@gmail.com², bin.antya@gmail.com ${ }^{3}$ \} \\ Balai Bahasa Provinsi Kalimantan Barat ${ }^{1,2,3,4}$
}

\begin{abstract}
Sufistic literature that is known today cannot be separated from the influence of previously established literary developments such as classical poetry in Arabic literary discourse. On the other hand, this is also inseparable from the influence of the development of Islam. Nasib; the ghazal element of qasidah, the convention of Arabic poetry, is the entrance to the Sufistic literature's formation. Thus, the Sufistic literary genre does have an epistemological basis, namely the history of classical Arabic literature and the development of Islamic thought. Ghazal and other elements as epistemological frameworks for Sufistic literature is an element that is studied and analyzed in this paper, which then form the Sufistic literature known to this day. The historical and philosophical approach is described through the relationship between literature and Sufism that characterizes the literary world on one side and the Sufistic world on the other.
\end{abstract}

Keywords: literature; sufism; creative imagination

\section{Introduction}

Arabic and Islam are inseparable, like two different sides of a coin. Arabic became the language of instruction for the Islamic messages conveyed by the Prophet Muhammad, the bearer of revelation. Islam influenced Arab traditions to be more civilized than before Islam was born. This synergy has been the building block of Islamic civilization for centuries. Arab tradition has developed before the arrival of Islam through the writing of ignorance (age of ignorance) of the Arabs who lack monotheism, not in other aspects. The proof is that Arabic knowledge before Islam was born has been able to reduce or minimize this stigma. Pre-Islamic Arabic literature already has knowledge in word processing and taste.

The literary tradition that had developed before Islam was present in Arab society is an example of its established knowledge. The literary tradition of a society is a sign that its civilization has gone one step further with an ordered sense of the word. Sociologically, Mahayana mentions that literary works are a mirror of life or a social mirror. Thus, Arab society has been able to describe conditions from all aspects of its aspects through its literary tradition [1].

In fact, Arab society has a social climbing arena (social climbers) called suq 'ukaz (Ukaz Market) for the pride of the literary media group. The genre of poetry is a literary medium used by Arab society to make each other proud of the group [2]. Poetry in Arabic discourse is 
called syi'ru (Arabic poetry) which is translated into poetry, which is written in the form of qasidah, conventional Arabic poetry. Besides Ukaz Market, there is also syi'ru al-mu'allaqat which means hanging poetry. Mu'allaqat is a collection of poems (poems) written in gold with scrolled stripes which are then hung on the walls of the Kaaba in the city of Mecca. The collection of poems is in the form of qasida (Arbic odes) (britannica.com.) [3]. Ukaz market, mu'allaqat, and qasida are part of the classical Arabic literature before Islam (Pre-Islamic) and means an ode of praise and honour [4].

As part of its treasures, qasidah is a literary convention written by Arab poets when writing poetry. Qasidah can be understood as a standard in writing poetry in the classical Arabic literary tradition. Likewise, old poetry, namely poetry and rhymes, in qasidah there are rules that must be observed. This rule was then used as an entry point for developing Sufistic literature, especially the ghazalah rules.

Qasidah have various themes, form the same poetic rhyme, and generally range in length from fifteen to eighty lines. The qasidah genre developed from its early history around the end of the fifth century, the general era during the pre-Islamic period (the age of ignorance) to its decline in the early twentieth century, bringing with it a long preservation of cultural heritage. Traditionally, qasidah is divided into three sections, namely nasib, rahil, and fakhr or madih [5]. On the other hand, in detail, Qasida (conventional ode, conventional Arabic poetry) later became a standard in classical Arabic poetry that must be considered. Some of the standards include the three sections previously mentioned above. These standards were written by an Arab poet before writing the contents of his poems.

Furthermore, Sutiasumarga divides the qasidah standard into eight principles, namely alHamasah, al-Fakhr, al-Madah, al-Rista, al-Hija', al-Wasfu, al-Ghazal, and al-I'tidzar [6]. These principles seem to replace the three previously mentioned sections, namely nasib, rahil, and fakhr or madih. In other words, these principles can be detailed into the three principles mentioned by Sumi.

Ghazalah grip or rules can be categorized as nasib because it contains definitions that have similarities. Nasib, is the opening section, dealing with sad motives such as the collapse of residence and relating to affectionate themes such as unrequited love [5]. Meanwhile, that ghazal is writing that explores the beauty of a woman's physical image such as the face, eyes, body, neck, teeth and so on, including visualizing the feelings of longing and the heart of the poet who boisterously rumbles towards the woman he admires. Ghazal also means describing the beauty of a woman he loves [6], [7].

Thus, there is a connection between ghazalah and nasib, that is the image of a woman's figure. In certain eras, female figures were often the imagery object in literary developments. Imagery could be defined as word or sentence that describe experience through sensory like visual, audiovisual, imaginary visual, and sense [8], [9], [10]. Moreover, ghazalah as the standard of classical Arabic poetry (qasidah) proves the existence of women in literary imaging which tends to be purely physical.

The existence of the ghazalah standard along with the development of Arabic poetry in the Age of Ignorance, did not benefit women sociologically. Such a situation in turn has an impact on women who occupy a position of inferiority in the literary image. Women are only seen on the side of domestication, focused on physical imagery that creates an erotic charm for a poet who is dominated by men.

The inferiority of women in the age of ignorance had an impact on gender inequality; women were only objects and had an impact on the style of writing poetry. Ghazalah is a marker of evidence that women and womenly were made a significant element of Arabic 
poetry in the early stages of its development and continues when women occupy the side of superiority in the process of imaginative creativity.

Therefore, the charm of women is indeed a source of eternal poetry inspiration. There are a broad range of erotic texts representing different approach, including women's act, prostitutes, body of the lover's praisal, and sexual metaphors [11]. The infinite variety of forms was a challenge to the Arabic desert poets, as did poets with refined mystical praise [12]. The charm of women who inspired Arabic poetry with the ghazalah grip seems to be used as a step stone for poets to initiate Sufistic literature as a separate genre.

Erotic in Arabic literary discourse is certainly related to the ghazalah standard in Arabic poetry conventions. The grip of ghaza is used as the entrance with all its shortcomings. As mentioned by Drozdik [12], almost the majority confirmed that it is related to the established poems of Arab mystics who use erotic imagination to express spiritual messages. Erotic images conventional Arabic poetry or qasidah are called ghazalah. It further strengthens the familiar statement in literary discourse that something does not experience a cultural vacuum. On the other hand, the intertextual theory is emphasized by the realization of certain forms of relationships between different texts, especially in literary texts, or the act of referring to one text to another. The spiritual messages of esoteric Sufistic literature have a relationship between the imagination and the erotic ghaza.

Therefore, the ghazalah as the starting point for the development of Sufistic literature needs to be studied historically when it is used as a standard in old Arabic poetry. His imaginative relationship is also part of the study to find the connection from erotic to esoteric. The philosophical framework of the scientific footing of Sufistic literature can be found through its constituent epistemological elements. Emphasizing that literature is not merely wishful thinking, but scientific as a view.

\section{Method}

This study applied a qualitative descriptive method, where the researchers describe how the relation of imagination-creative of sufistic literature change from erotic to esoteric perspective. At the data analysis stage, the data were compiled by relating the literature based to the research focus without gathering the data in the research field [13], [14], [15].The last stage of the implementation of this research is the presentation of the results of data analysis. Data is presented using an informal method, namely the method of presenting the results of data analysis using ordinary words, including the use of technical terminology [16].

\section{Result and Discussions}

\subsection{Results}

Scientific philosophy is a consideration that must be taken to rest on a fixed fundamental basis. Ghazalah is a fundamental foothold which in turn forms mystical Islamic literature which is still developing today. Thus, the ghazalah needs to be discussed in order to know its urgency in relation to Sufistic literature.

\subsubsection{Language Approach}


In Mu'jam al-Ma'aniy it is explained that ghazala is fi'ilmujarrad (basic word) which means lengthening and collecting cotton into threads to be used as wool fabric with tools [17]. On the other hand, ghazala means the excitement of talking and having fun with women or describing their nature. However, it is more specifically mentioned that ghazala means poetry that is said about women with their natural beauty and charm [17]. From the word ghazala, there are indeed several meanings, including about women physically including the name of an animal, deer. In the language approach, it is stated that ghazala has the meaning of poetry that portrays the beauty and charm of women. Thus, her beauty and charm is the beginning that triggers eroticism on the part of the beholder. The charm and beauty that lies behind a poet (writer) accumulates through a row of words on behalf of women with eroticism.

\subsubsection{Historical Approach}

Sufism literature did not just appear, but through a long history. Beginning in pre-Islamic times, classical Arabic literature emerged with its conventional poetry, qasida. Then in the Islamic era in the second century Hijri or the eight century, Sufism emerged with the zuhud movement (aescheticism). According to Ernst, to know and appreciate the aesthetics of Sufi poetry, we must first acknowledge the emergence and role of pre-Islamic Arabic poetry in shaping Islamic culture [18], [19], [20]. Esoteric poetry (Sufistic poetry) as an Islamic culture then cannot escape the role of erotic poetry (al-ghazalah). It seems that it is clear that the emergence of art forms is closely related to the existence of previous arts, including literary arts.

Therefore, the ghazalah is part of the conventional nasib as a whole, which is the based convention in arranging subsequent Sufistic poetry. The choice of ghazalah as a medium of transformation from erotic poetry to esoteric poetry is because the object of praise is a woman. This human figure can give the effect of closeness to the poet and this closeness is built in esoteric poetry to Allah.

Furthermore, Ernst also concluded that the Prophet Muhammad's apostolate brought about enormous changes in human life that brought about an ethical and moral revolution, including the aesthetics of Arabic literature. Therefore, Sufistic poetry is strongly influenced by the apostolate of Prophet Muhammad so that the principles of qasida, such as the worship of tribal wars (al-hamasah), wine (al-khamriah), profanistic love (ghazal), and pride (al-fakhr) has been replaced by submission to Allah.

A similar opinion was also conveyed by Hadi regarding Sufistic poetry which was strongly influenced by the apostolate of the Prophet Muhammad [21]. Sana'i (1131) in Hadi describes the Sufi theory of God, the apostleship of the Prophet Muhammad, makrifat, tawakal, heaven, philosophy, and love. This book is a work of early Sufistic literature. Sufistic literature reached its peak of development in the XII to XIV centuries with the emergence of Sufistic experts who were also great poets and aesthetic experts, such as Sana'i, Fariduddin al-Attar, IbnArabi, Ruzbihan al-Baqli, Nizami, Sa'di, Jalaluddin al-Rumi, Iraqi, Mahmud Syabistarri, Hafiz, and Jami'. Including the famous Sufistic poet Syarafuddin Umar Ibn Farid, who was known as Ibn Farid (1182-1235) [22].

\subsubsection{Erotic Poetry}

The term 'erotic' defined by Merriam-Webster Dictionary as: of, defoted to, or tending to arouse sexual love or desire; strongly marked or affected by sexual desire [23]. Moreover, Oxford Learner's dictionary stated that erotic is showing or involving sexual desire and 
pleasure; intended to make somebody feel sexual desire [24]. Referring to those meaning, erotic literature means literature whose main theme is about passionate love. The connection with conventional Arabic poetry contained in the convention of ghazalah which means expressing the beauty and charm of women, the female figure is physically expressed in poetry. Ibn Rasiq's statement provides an illustration related to eroticism in conventional Arabic poetry expressed in Arabic.

Wa kanat al-qabilatu min al-'Arabi 'idza nabagha fiha sya'irun 'atat al-qaba'ilu fahanna'atha bidzalika wa sunni'at al-'at'imatu wajtama'at al-nisa'u yal'abna kama yasna'na fi al-'a'rasi wa tabasyara al-rijalu wa al-walidani. (An Arab tribe (kabilah) when the poet is famous, other tribes come and congratulate, banquets are held, women gather to play the harp as they do at weddings, and people young and old rejoice with good news [12].

Ibn Rasyiq seems to explain that the position of the poet in a tribe, which has a high reputation, is very calculated. Not only was his own tribe hailed, but other tribes also congratulated him with a feast. The erotic statement is that there is a group of women playing the harp, which is the same thing done at a wedding. Women playing musical instruments can cause erotic effects, invite lust or sexual libido. This kind of event invites people to gather to celebrate the success of the poet. The existence of women becomes an attraction because of their erotic allure. Ibn Rasyiq wants to say that women's eroticism is clearly expressed even though there is no direct relationship with the literature itself. Another erotic Arabic poetry, discoverd in the article, Erotic Imagery in Classical Arabic Poetry, in the international journal Asian and African Studies, written by Ladislav Drozdik in 1997 [12]. The article contains erotic poems.

Wa fi al-hayyi ahwa yanfudu al-muradu syadin*madhahiru sumtiyyi lu'lu'i wa zabrajid (In the dark, the deer child breaks down the Arak* two pearl necklaces and topaz are seen).

In Drozdik's explanation, it is stated that the word hwa means dark (deer gums) which when it comes out of the tribe, it looks like pearls and topaz. Apparently, the erotic depicted that a girl's gums are like two sheen of pearls and topaz.

Tasuddu wa tubdi 'an asili wa tattaqa*binadziratin min wahsyi wa jarrat mitfalu (He looked away to cover his face, and guarded with a flash of a deer wajra)

Wa ka'anna farat tajiraini biqasimatin*sabaqat 'awariduha ilayka min al-fami (Like a merchant's musk basket there is a perfume box before the sides of his teeth for you from the mouth)

Wa ma darafat 'aynaki illa litadribi*bisahmika fi asy'ari qalbi muqtali (Your eyes don't flow except for my practice with your two arrows in the deadly recesses of the heart).

As mentioned above, erotic related the physical image of women. In those poems what is revealed is the face, the arrangement of teeth, and the two eyeballs of women. Other poems contained in the article also portray the physical parts of women. Women's physique with eroticism becomes the spotlight of tribal poets in their poetry. Thus, women become objects of physical erotic imagery in the conventions of classical Arabic poetry. Physically, it is easy for women to arouse feelings or to ignite basic human desires. The female figure is the center of the expression that gives rise to the subtle side of the human libido, in addition to the patriarchal factor in the past, including in the past (age of ignorance) of Arab society [25]. In fact, the relationship between men and women should be acquired the respectability and solemnity of their status [26].

\subsubsection{Esoteric Poetry}


Esoteric is inner (eso-) meaning within or understood as awareness that comes from within, contemplatively means the perspective of personal transformation through mysticism (Sufism) and meditation. Something different from everyday understanding, can only be understood through intuition, high spirituality, or spiritual ability.

Esoteric is closely related to Sufism or Islamic mysticism if understood in Islamic discourse. In tradition of Sufism, the existence of God's love always be accepted by His creation [27]. In this case, esoteric poetry is certainly poetry that contains and expresses Sufism, there are three parts, namely al-ghazl al-hudriy, al-ghazl al-'udriy, and al-ghazl altaqlidy. These three forms were developed by the poets in qasidah during the age of ignorance period. The use of the term al-ghazl is related to the development of previous classical Arabic conventional poetry, one of the conventions is al-ghazalah or al-nasib.

First, al-ghazl al-hudriy is also called al-ghazl al-hissiy, this form developed in the midst of the people of Mecca and Medina, driven by Umar bin Abi Rabi'ah. According to Toha Husein, this ghazl is also called al-muhaqqiqin because it is based on the reality that occurs, grounding love, not exalting love. However, all love is free from material form in order to realize love with a clear meaning (Muhammad 'Uthman 'Aliy, Fi al-'Adabiy al-Islamiy 'Asr alNubuwwat wa al-Rasyidin wa Bani Umayyah, Kuliiyat al-Da'wah al-Islamiyyah [28], [29].

Both al-ghazl al-udhriy or al-afif, this form comes from the poets of the Hijaz and Najd valleys, closely related to Bani Udhrat, one of the poets is Jamil Buthainah. This tribe lives in a transitional period, nomadic (village), old and settled life (city), new life. These poets rested on a new spirit and were comfortable with a new life. Husein in Fuad stated that the new life in question is the life of Islam and rests on simplicity with the spirit of Islam [28]. Furthermore, this ghazl rests on one lover, in contrast to al-ghazl al-hudriy, alternates lovers and is full of Islamic meanings, such as the use of the diction asyku that means:'I complain, complain to Allah for a burning and vengeful longing', such as the poem below.

'Ila Allahi 'asyku faqad labbani kama syaka*'ila Allahi faqada al-walidaini yatimu (My complaint to Allah binds me like a complaint to Allah an orphan who has lost both parents)

'Ila Allahi 'asyku la ila al-nasi hubbaha*wa la budda man syakwa habibu yaru'u (I complain of his love for Allah not for humans * lovers must thrill complaints)

This ghazl rests also on love with an absolute pure image without being entered by passing thoughts. These ghazl poets contributed to the development of language significantly more than before during the age of ignorance and the first half of the Islamic period. The existence of a new paradigm, Islamic thought, at that time was part of the synthesis so that it influenced the previous period, including the influence of language (Muhammad 'Utsman 'Aliy, Fi al'Adabiy al-Islamiy 'Asr al-Nubuwwat wa al-Rasyidin wa Bani 'Umayyah, Kuliiyat al-Da'wah al-Islamiyyah [28].

The third al-ghazl al-taqlidiy is an old form of qasidah which is still being developed by poets. The form of the poem is the same as that of classical conventional Arabic poetry by opening it with nasib. This poem is preceded by memories to the lover about his home, the twists and turns of his journey, and its qualities (Muhammad 'Utsman 'Aliy, Fi al-'Adabiy alIslamiy 'Asr al-Nubuwwat wa al-Rasyidin wa Bani 'Umayyah, Kuliiyat al-Da'wah alIslamiyyah [28]. The keyword taqlidiy is a form of this ghazl, meaning it follows the previous form, namely nasib of classical conventional Arabic poetry.

The three forms of ghazalah Arabic poetry above, the form of al-ghazl al-'udhriy or al-'afif is a form that synergizes from erotic poetry to esoteric poetry. Through this form, there is a change in creative imagination, which initially rested on women as lovers, moving to God as 
lovers $(a l-m a h b u b)$. Meanwhile, love $(a l-h u b)$ remains the basis initially in erotic poetry and later in esoteric poetry.

It seems that from the form of al-ghazl al-'udhriy or al-'afif it becomes a stepping medium for the transformation of the creative imagination of Sufistic poetry which is more sophisticated. It can be understood because the development and expansion of Islamic territory is increasingly widespread, so that outside influences cannot be avoided. Then, the Islamic scientific tradition lives in the midst of Islamic society so that the process of religious thinking is built easily. The creative imagination of the ghazalah is a transformation of erotic poetry into esoteric poetry through the influence of the arrival of Islam (sadr al-'Islam) which has a significant impact. It is also related to Islamic culture in which people must do worship to God as he always see what people do [30].

Ghazalah is no longer a form of Arabic poetry that is based on love for creatures (women), but is changed to love for the Creator (Allah). Therefore, esoteric poetry (Sufistic) is well established and even becomes a genre, there is an epistemological scientific process. Esoteric poetry creativity is based on science and history, science is based on divine love and history, namely the position of the ghazalah as a creative space in nasib of conventional classical Arabic poetry.

\subsection{Discussion}

The relationship between eroticism and art has actually been around for a long time. Erotic elements become part of the art of dance, fine arts, theater arts, including literary arts. Meanwhile, in classical Arabic literature there is the term ghazalah or nasib which means poetry (syi'ri) which portrays the erotic image of women. Ghazalah or nasib is part of the conventions of classical Arabic poetry along with other conventions (conventional of classical Arabic poetry).

The position of women in the classical period was more likely to become an understandable object because the construction of society used to be related to patriarchy. Men as a group dominate all aspects of life, including women's aspects. Women are used as frames for art imaging objects, including literature. On the other hand, the period of ignorance in classical Arab society can be called a period of discrimination against women.

That period cannot be understood as a period of ignorance through evidence of his familiarity with the world of literature, especially poetry in Arabic terminology, syi'ru. Poetry is so closely related to the life of Arab society that it functions as a means of group identity existence because Arab society has numbers of tribes, including a means of self-expression of women's images. As already mentioned in the background, the image of women in classical Arabic poetry conventions is called ghazalah or nasib. In Mu'jam al-Ma'aniy it is stated that nasib is a ghazalah poem, a love poem, and his attention is directed to women [17]. Meanwhile, nasib refers to a series of expressions, including ghazalah or accompanying the poet loved by the convention.

\section{Conclusion}

Literary and Sufistic relations have been built since the beginning of the ghazalah as a medium of creative imagination in a transformative framework from erotic poetry to esoteric poetry. Historically, the existence of classical Arabic poetry through the conventional which is summarized in nasib with ghazalah is one of the discourses of this transformation. The 
existence of the Islamic period gave a significant influence by leading to the love of God, which was then the existence of Sufistic poetry (literature) as an esoteric discourse.

Philosophically, Sufistic poetry is based on ghazalah, the foundation of creative imagination, which has developed previously, while its limits are a sense of love for God. Indirectly confirming the literary statement that is understood, that literature does not grow in an empty space. Ghazalah is a content space that develops esoteric poetry.

In the two discourses between literature and Sufism show the interdisciplinary relationship of two different disciplines, including the beginning of the emergence of different times. However, literature is actually a discipline that is related to other disciplines, such as Sufism. Meanwhile, the Sufistic character with the khayyaliyah (imaginative) dimension is closely related to literature as a representative medium for the imaginative side.

\section{References}

[1] M. S. Mahayana, 9 Jawaban Sastra Indonesia Sebuah Orientasi Kritik. Jakarta: Bening Publishing, 2005.

[2] B. M. R. et. al Bustam, Sejarah Sastra Arab dari Beragam Perspektif. Banda Aceh: Deepublish, 2015.

[3] NN, "Al-Mu'allaqat," britannica.com. 2019, Accessed: Dec. 26, 2019. [Online]. Available: https:/www.britannica.com/topic/Al-Muallaqat-Arabic-literature.

[4] A. Armstrong, Sufi Terminology (Al Qamus Al Sufi) The Mystical Language of Islam A.S. Kuala Lumpur: Noordeen, 1995.

[5] A. M. Sumi, Description In Classical Arabic Poetry. Leiden, Netherlands: Brill-Leiden Boston, 2004.

[6] M. Sutiasumarga, Kesusastraan Arab Mula dan Perkembangannya. Jakarta: Zikrul Hakim, 2001.

[7] N. Hamim, "Syair Ratapan (Ritsa) dan Cinta (Ghazal) dalam Budaya Perang Bangsa Arab Jahiliyah (Kajian Sosiologi Sastra)," Nuansa, vol. 9, no. 2, pp. 335-352, 2012, doi: https://doi.org/10.19105/nuansa.v9i2.158.

[8] C. Wirawan, Gunta, Effendy, Chairil, \& Syam, "Membaca Odhy's (Suatu Tinjauan Etika Pofetik)," J. Pendidik. dan Pembelajaran Khatulistiwa, vol. 4, no. 3, pp. 1-16, 2015.

[9] H. J. Waluyo, Apresiasi Puisi untuk Pelajar dan Mahasiswa. Jakarta: PT. Gramedia Pustaka Utama, 1991.

[10] E. Kosasih, Dasar-dasar Keterampilan Bersastra. Bandung: CV. Yrama Widya, 2012.

[11] E. M. G. Jimenez, "Review of E. E. Cummings, Erotic Poems (Norton, 2010)," www.researchgate.net,

2010. https://faculty.gvsu.edu/websterm/cummings/Gomez18.pdf (accessed Sep. 24, 2021).

[12] L. Drozdík, "Erotic Imagery in Classical Arabic Poetry," Asian Afr. Stud., vol. 6, no. 1, pp. 21-44, 1997, Accessed: Jan. 03, 2020. [Online]. Available: https:/www.medievalists.net/2011/10/erotic-imagery-in-classical-arabic-poetry/.

[13] G. Wirawan, "Dimensi Trandensi dalam Antologi Puisi Rahasia Sang Guru Sufi Karya Odhy's," Dialekt. J. Bahasa, Sastra, dan Pendidik. Bhs. dan Sastra Indones., vol. 5, no. 2, pp. 196-218, 2018, doi: 10.15408/dialektika.v512.9834.

[14] J. U. Muliawan, Metode Penelitian Pendidikan dengan Studi Kasus. Yogyakarta: Penerbit Gava Media, 2014.

[15] M. Zed, Metode Penelitian Kepustakaan. Jakarta, 2008. 
[16] Sudaryanto, Metode Linguistik Bagian Pertama ke Arah Memahami Metode Linguistik. Yogyakarta: Gadjah Mada University Press, 1988.

[17] NN, AlMaany Dictionary. 2021.

[18] C. W. Ernst, Ajaran dan Amalan Tasawuf. Yogyakarta: Penerbit Pustaka Sufi, 2003.

[19] K. Fuad, "Simbolisme Pisi Sufistik Odhy's (Kajian Antologi Puisi Rahasia Sang Guru Sufi)," ATAVISME, vol. 23, no. 1, pp. 75-88, 2020, doi: 10.24257/atavisme.v23i1.622.75-88.

[20] M. Budianta, "Simbolisme, Imajisme, dan Sastra Indonesia," in Simbolisme dan Imajisme dalam Sastra Indonesia, Jakarta: Pusat Bahasa Kementerian Pendidikan Nasional, 2010, p. 3.

[21] A. W. M. Hadi, Tasawuf Yang Tertindas Kajian Hermenetika Terhadap Karya-Karya Hamzah Fansuri. Jakarta: Paramadina, 2001.

[22] R. A. Nicholson, Studies in Islamic Mysticism. London: Cambridge University Press., 1980 .

[23] NN, "Merriam-Webster Dictionary," www.merriam-webster.com. https://www.merriam-webster.com/dictionary/erotic (accessed Sep. 27, 2021).

[24] NN, "Oxford Learner's Dictionaries," www.oxfordlearnersdictionaries.com/, 2021. https://www.oxfordlearnersdictionaries.com/definition/english/erotic?q=erotic (accessed Sep. 27, 2021).

[25] C. Buana, Citra Perempuan dalam Syair Jahiliyah. Yogyakarta: Mocopat Offset, 2010.

[26] R. K. Peeran, S L, Singh, Esoteric, Aesthetic and Metaphysical Poetry of R.K. Singh An analysis. India: Modern Indian English Project, 2021.

[27] et al Howell, Julia, "Sufism on the Silver Screen Indonesian Innovations in Islamic Televangelism," J. Indones. Islam, vol. 2, no. 2, pp. 225-239, 2008, [Online]. Available: http://jiis.uinsby.ac.id/index.php/JIIs/article/view/31/31.

[28] K. Fuad, "Tasawuf Dalam Puisi Arab Modern (Studi Puisi Sufistik 'Abd al-Wahab alBayati)," IAIN Walisongo, Semarang, 2004.

[29] M. Z. Azizah, Qois \& Sya'bani, "Integrasi Sastra Arab dan Islam serta Pengaruhnya terhadap Sastrawan Muslim Modern," Al Fathin, vol. 3, no. 2, pp. 140-156, 2020, [Online]. Available: https://e-journal.metrouniv.ac.id/index.php/alfathin/article/view/3099/2075.

[30] E. Al-Haramain, "Shifting Orientation in Sufism: its development and doctrine adjustment in history," Indones. J. Islam Muslim Soc., vol. 1, no. 2, pp. 273-296, 2011, [Online]. Available: https://ijims.iainsalatiga.ac.id/index.php/ijims/. 